Note

\title{
COOLING PARAMETERS FOR FRUITS AND VEGETABLES OF DIFFERENT SIZES IN A HYDROCOOLING SYSTEM
}

\author{
Bárbara Teruel $^{1 *}$; Theo Kieckbusch²; Luis Cortez ${ }^{1}$ \\ ${ }_{2}^{1}$ UNICAMP/Faculdade de Engenharia Agrícola, C.P. 6011 - 13083-970 - Barão Geraldo - Campinas, SP - Brasil. \\ ${ }^{2}$ UNICAMP/Faculdade de Engenharia Química, C.P. 6066 - 13083-970 - Barão Geraldo - Campinas, SP - Brasil. \\ *Corresponding author <barbarat@agr.unicamp.br>
}

\begin{abstract}
The cooling of fruits and vegetables in hydrocooling system can be a suitable technique. This work aimed to define cooling time for fruits and vegetables of different sizes, presenting practical indexes that could be used to estimate cooling time for produce with similar characteristics. Fruits (orange melonCucumis melo, mango-Mangifera indica, guava-Psidium guajava, orange-Citrus sinensis Osbeck, plumPrunus domestica, lime-Citrus limon, and acerola-Prunus cerasus) and vegetables (cucumber-Cucumis sativus, carrot-Daucus carota, and green bean-Phaseolus vulgaris), were cooled in a hydrocooling system at $1^{\circ} \mathrm{C}$. The volume of fruits and vegetables ranged between $8.18 \mathrm{~cm}^{3}$ and $1,150.35 \mathrm{~cm}^{3}$, and between 13.06 $\mathrm{cm}^{3}$ and $438.4 \mathrm{~cm}^{3}$, respectively. Cooling time varied proportionally to produce volume (from 8.5 to 124 min for fruits, and from 1.5 to $55 \mathrm{~min}$, for vegetables). The relationship between volume and time needed to cool fruits (from $1.03 \mathrm{~min} \mathrm{~cm}^{-3}$ to $0.107 \mathrm{~min} \mathrm{~cm}^{-3}$ ) and vegetables (from $0.06 \mathrm{~min} \mathrm{~cm}^{-3}$ to $0.12 \mathrm{~min}^{-3}$ ) is an index that could be used to estimate cooling time for fruits and vegetables with similar dimensions as those presented in this work.
\end{abstract}

Key words: cooling time, product volume, sphericity

\section{PARÂMETROS DE RESFRIAMENTO DE FRUTAS E HORTALIÇAS DE DIFERENTES DIMENSÕES EM UM SISTEMA COM ÁGUA FRIA}

\begin{abstract}
RESUMO: O resfriamento com água gelada pode ser uma técnica adequada para frutas e hortaliças frescas. Este trabalho teve como objetivo obter o tempo de resfriamento de frutas e hortaliças de dimensões diferentes, e apresentar índices práticos que possam ser usados para estimar o tempo de resfriamento de produtos com características semelhantes. Frutas (melão-Cucumis melo, manga-Mangifera indica, goiaba-Psidium guajava, laranja-Citrus sinensis Osbeck, ameixa-Prunus domestica, limão-Citrus limon e acerola-Malpighia glabra) $\mathrm{e}$ hortaliças (pepino-Cucumis sativus, cenoura-Daucus carota e vagem-Phaseolus vulgaris), foram resfriadas num sistema por imersão em água à $1^{\circ} \mathrm{C}$. O volume das frutas oscilou de $1150,35 \mathrm{~cm}^{3}$ a $8,18 \mathrm{~cm}^{3}$ e das hortaliças entre $438,4 \mathrm{~cm}^{3}$ a $13,06 \mathrm{~cm}^{3}$. O tempo de resfriamento variou proporcionalmente com o volume dos frutos, de 8,5 min até $124 \mathrm{~min}$ (frutas) e de 1,5 $\mathrm{min}$ até $55 \mathrm{~min}$ (hortaliças). Foi calculado o índice relacionando volume e tempo de resfriamento das frutas $\left(1,03 \mathrm{~min} \mathrm{~cm}^{-3}\right.$ a $\left.0,107 \mathrm{~min} \mathrm{~cm}^{-3}\right)$ e hortaliças $(0,06$ $\operatorname{min~} \mathrm{cm}^{-3}$ a $0,12 \mathrm{~min} \mathrm{~cm}^{-3}$ ), que pode ser usado para a estimativa do tempo de resfriamento de frutas e hortaliças com dimensões semelhantes.
\end{abstract}

Palavras-chave: tempo de resfriamento, volume dos produtos, esfericidade

\section{INTRODUCTION}

In tropical climate, where mean annual temperatures can exceed $32^{\circ} \mathrm{C}$, fresh fruit losses reach up to $30 \%$. Temperature plays a very important role in the preservation of recently-harvested products. To achieve a rapid and efficient decrease in product temperature, the use of fast-cooling systems is particularly important.

The use of systems utilizing cool water (hydrocooling) is an interesting technology, allowing high heat-transfer rates, which can result into three timesshorter cooling times in comparison with products cooled by forced air, or ten times, when products are placed in conventional or storage room (Mitchell, 1992; Talbot \& Chau, 1991; Delgado \& Wen Sun, 2001; Fraser \& Otten, 1992; Teruel et al., 2002).

Fruits with different geometries and sizes are cooled differently when submitted to similar conditions (Baird \& Gaffney, 1976). Oranges $(r=3.75 \mathrm{~cm})$ hydrocooled at $1^{\circ} \mathrm{C}$ reach cooling temperature in 57.5 min, while limes $(r=3.01 \mathrm{~cm})$ are cooled in $30 \mathrm{~min}$ (Teruel et al., 2001; 2002).

The objective of this work was to define cooling time for fruits and vegetables of different dimensions, establishing the relation between time and products volume, in order to present practical indexes that could be 
used to estimate the cooling time of products with similar characteristics to those presented in this work.

\section{MATERIAL AND METHODS}

\section{Cooling experiments}

Melon, mango, guava, orange, lime, acerola, and plum, with different sizes and an approximate spherical geometry, and cucumber, carrot, and green bean, with an approximate cylindrical geometry (Figure 1), all harvested in Campinas region, were submitted to cooling in an immersion-type cooling system with water circulation. The refrigeration system consisted of hermetic compressor, air condenser, thermostatic expansion valve, water tank, and circulation pump. The water tank $(780 \times 580 \times 570 \mathrm{~mm})$ had a $0.23 \mathrm{~m}^{3}$ capacity and a water flow of $0.001 \mathrm{~m}^{3} \mathrm{~s}^{-1}$, insulated with fiberglass $(5 \mathrm{~cm})$ coated with asphalt membrane (Figure 2a). The water was treated with an active chlorine solution $\left(150 \mathrm{mg} \mathrm{L}^{-1}\right)$. The water temperature within the immersion tank was measured with thermocouples $\left(1 \pm 0.4^{\circ} \mathrm{C}\right)$.
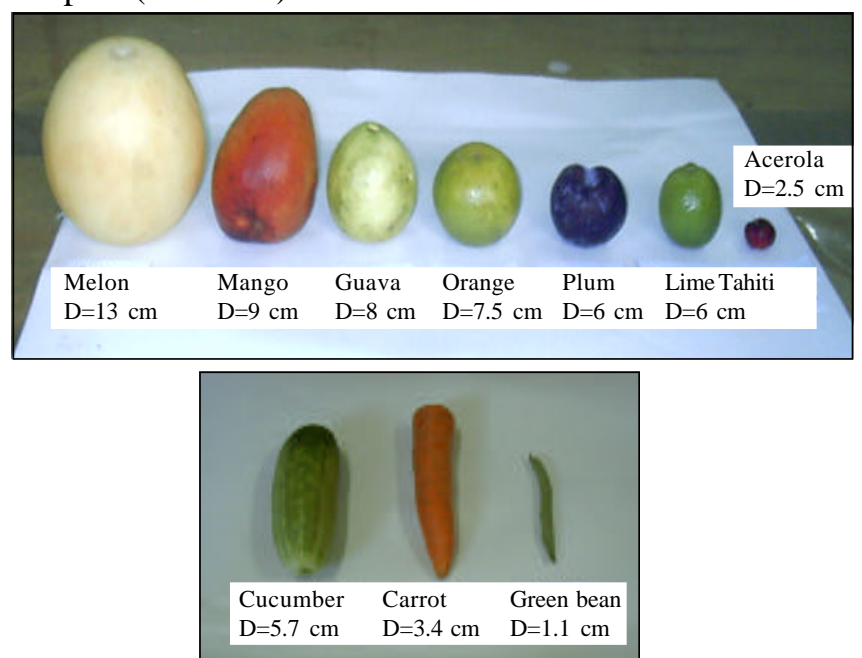

Figure 1- Fruits and vegetables hydrocooled at $1^{\circ} \mathrm{C}$
Fruit temperature was measured with type $\mathrm{T}$ thermocouples (Cu-Co, AWG \# 28), calibrated to the nearest $\left( \pm 0.15^{\circ} \mathrm{C}\right)$. Thermocouples were inserted into the fruits according to the $\mathrm{r} / 4$ (spherical products) or $\mathrm{r} / 3$ (cylindrical products) relation (Van der Sman, 2003). The longitudinal (rL) and transversal (rT) radius were measured with a caliper rule, and fruit sphericity was calculated based on the data $(E=r T / r L)$. In vegetables, radius and length were measured. Before performing the experiments, the fruits and vegetables were weighed on digital scale.

The thermocouples were inserted into three products contained in the packaged (Figure $2 b$ ). The products (15 kg in each experiment), were packaged within a perforated, wire mesh package $(450 \times 300 \times 300 \mathrm{~mm})$ and transported in the first hours of the day to the laboratory.

A computerized data-acquisition system was used to acquire and monitor temperature data. The system consisted of an A/D converter, a signal conditioning card, and a microcomputer. Readings were stored into files for later analysis and processing.

\section{Cooling time}

Cooling time is a parameter that can be used to evaluate the efficiency of fast-cooling systems for commercial and/or research purposes. Two terms related to cooling time are considered, namely half cooling time $\left(\mathrm{TAT}_{1 / 2}\right)$, and seven-eight cooling time $\left(\mathrm{TAT}_{7 / 8}\right)$. This parameter (time) can be determined by the Dimensionless Temperature Rate (TAT) (ASHRAE, 1994; Mohsenin, 1980):

$$
T A T_{(1 / 2)}=\frac{T p-T a}{T i-T a}=0.5 \quad T A T_{(7 / 8)}=\frac{T p-T a}{T i-T a}=0.125
$$

where $\mathrm{Tp}$ is the temperature measured in the product during cooling, $\mathrm{Ti}$ is the initial temperature of the fruit, and Ta is the temperature in the cooling medium (water at $1^{\circ} \mathrm{C}$ ).

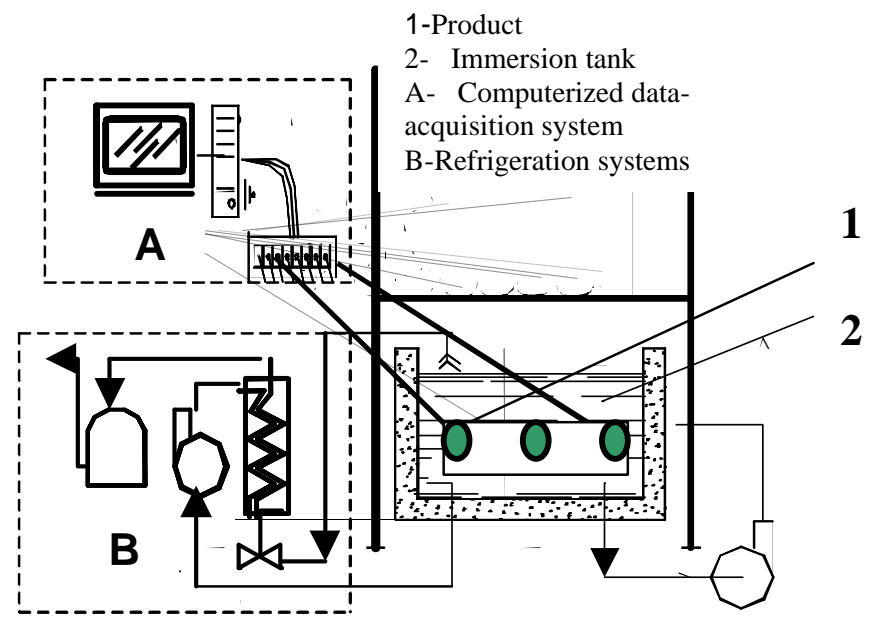

(a)

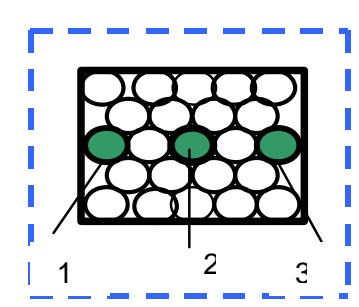

(b)

Figure 2 - a) Elements comprising the immersion refrigeration system. b) Position in the fruits where temperature was measured. 


\section{RESULTS AND DISCUSSION}

\section{Cooling of fruits}

Mean initial temperature of fruits was $25.1 \pm$ $0.9^{\circ} \mathrm{C}$. Cooling time of all fruits varied proportionally with volume, temperatures dropping to $12.5^{\circ} \mathrm{C}\left(\mathrm{TAT}_{1 / 2}\right)$ and $3.2^{\circ} \mathrm{C}\left(\mathrm{TAT}_{7 / 8}\right)$ in time spans ranging from 8.5 min to 125 min. Larger fruits were cooled in time intervals 14 times longer than smaller fruits (Figure 3).

Dincer et al. (1992) cooled $15 \mathrm{~kg}$ of peaches $(\mathrm{r}=2.3 \mathrm{~cm})$, plums $(\mathrm{r}=1.85 \mathrm{~cm})$, and pears $(\mathrm{r}=2.8 \mathrm{~cm})$ in a hydrocooling system at a temperature of $1^{\circ} \mathrm{C}$; cooling times were $17 \mathrm{~min}, 15 \mathrm{~min}$, and $25 \mathrm{~min}$, respectively. Pears reached the seven-eight cooling time in intervals $47 \%$ to $66 \%$ longer. Lime, orange, guava, and melon showed higher sphericity values $(\mathrm{E}=1.01$ to 1.06 , with a slightly prolate geometry) than acerola and plum ( $\mathrm{E}=$ 0.97 to 0.99 , with a geometry tending to oblate shape), differently from mango $(\mathrm{E}=1.12)$, which presented a more prolate geometry (Table 1).

\section{Cooling of vegetables}

The mean initial temperature of vegetables was $24.8 \pm 0.4^{\circ} \mathrm{C}$, and the half cooling and seven-eight cooling times were attained when they reached a temperature of approximately $12.4^{\circ} \mathrm{C}$ and $4.1^{\circ} \mathrm{C}$ (Figure 4). Cucumber required 36 times longer time than green bean (37\%) to reach $4^{\circ} \mathrm{C}$ temperature, as a result of the difference in volume between both vegetables, which was $97 \%$ higher (Table 2).

The time period will be longer depending on the final temperature intended for the product. Dincer \& Genceli (1994) cooled $20 \mathrm{~kg}$ of cucumbers (D=3.8 $\mathrm{cm}$ and $\mathrm{L}=16 \mathrm{~cm}$ ) to $4^{\circ} \mathrm{C}$ in $33 \mathrm{~min}$ (seven-eight cooling time) in a hydrocooling system.
The indexes presented in this work, relating cooling time and volume, could be used to estimate cooling time for fruits and vegetables with similar dimensions For instance, for melons with $1300 \mathrm{~cm}^{3}$, index $0.107 \mathrm{~min}^{-3}$, the approximate time to reach seven-eighth cooling $\left(\approx 3^{\circ} \mathrm{C}\right)$ would be $139 \mathrm{~min}$. Green beans with $18 \mathrm{~cm}^{3}$ would cool to $3^{\circ} \mathrm{C}$ in approximately $2 \mathrm{~min}$.

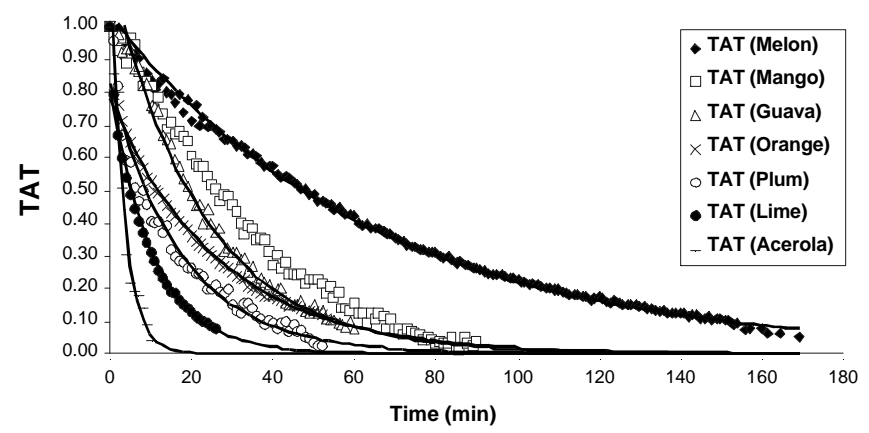

Figure 3 - Cooling rates of fruits hydrocooled at $1^{\circ} \mathrm{C}$.

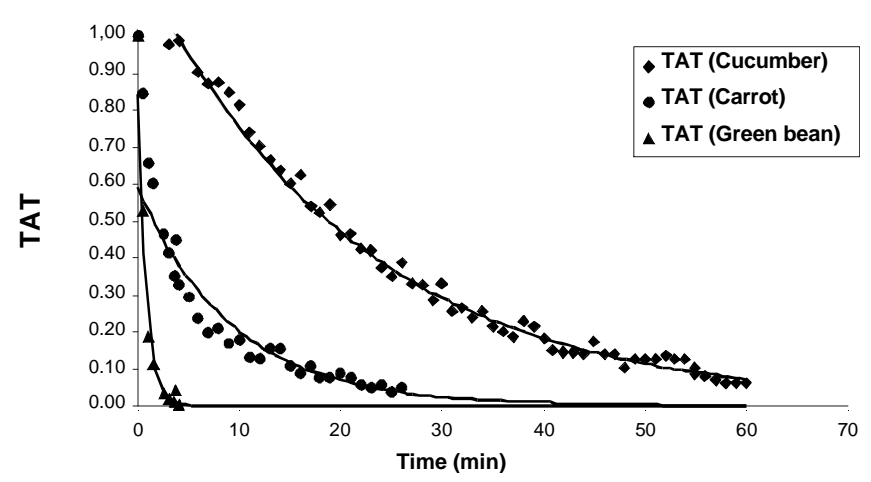

Figure 4 - Cooling rates of vegetables (cucumber, carrot, green bean) hydrocooled at $1^{\circ} \mathrm{C}$.

Table 1 - Cooling time, cooling time/volume ratio and sphericity of fruits cooled with water at $1^{\circ} \mathrm{C}$.

\begin{tabular}{|c|c|c|c|c|c|}
\hline Products & TAT $1 / 2$ & TAT $7 / 8$ & Volume $\left(V=4 / 3 \pi r^{3}\right)$ & Cooling time/volume rati & Sphericity \\
\hline & - & $\min -\ldots-\ldots-1$ & $\mathrm{~cm}^{3}$ & $\min \mathrm{cm}^{-3}$ & $\mathrm{E}$ \\
\hline Acerola & $3.0 \pm 1.5$ & $8.5 \pm 3.0$ & $8.18(\mathrm{r}=1.25 \pm 0.18 \mathrm{~cm})$ & 1.03 & $0.99 \pm 0.02$ \\
\hline Santa Rosa Plum & $5.0 \pm 2.0$ & $19.0 \pm 4.2(0$ & $87.11(\mathrm{r}=2.75 \pm 0.12 \mathrm{~cm})$ & 0.218 & $0.97 \pm 0.02$ \\
\hline Tahiti Lime & $7.0 \pm 2.1$ & $28.5 \pm 2.1$ & $113.10(\mathrm{r}=3 \pm 0.10 \mathrm{~cm})$ & 0.251 & $1.01 \pm 0.02$ \\
\hline Valência Orange & $13.0 \pm 1.8$ & $44.5 \pm 1.8$ & $220.89(\mathrm{r}=3.75 \pm 0.12 \mathrm{~cm})$ & 0.202 & $1.02 \pm 0.02$ \\
\hline White Guava & $19.0 \pm 1.8$ & $51.0 \pm 2.2$ & $268.08(\mathrm{r}=4 \pm 0.11 \mathrm{~cm})$ & 0.190 & $1.06 \pm 0.031$ \\
\hline Tommys Mango & $25.0 \pm 1.3$ & $60.5 \pm 2.5$ & $381.70(\mathrm{r}=4 \pm 0.15 \mathrm{~cm})$ & 0.158 & $1.12 \pm 0.02$ \\
\hline Orange Melon & $45 \pm 4.1$ & $124.0 \pm 3.4$ & $1150.35(\mathrm{r}=6.5 \pm 0.10 \mathrm{~cm})$ & 0.107 & $1.01 \pm 0.007$ \\
\hline
\end{tabular}

Table 2 - Cooling time and cooling time/volume ratio of hydrocooled vegetables.

\begin{tabular}{lrrrc}
\hline Products & TAT $1 / 2$ & TAT 7/8 & Volume $\left(\mathrm{V}=\pi \mathrm{r}^{2} \mathrm{~h}\right)$ & Cooling time/volume ratio \\
\hline & -1.0 & $\mathrm{~cm}^{3}$ & $\mathrm{~min}^{-3}$ \\
Cucumber & $21.0 \pm 2.1$ & $55.0 \pm 2.0$ & $438.4(\mathrm{r}=3.01 \pm 0.19 \mathrm{~cm} ; \mathrm{L}=17.18 \pm 0.75 \mathrm{~cm})$ & 0.12 \\
Carrot & $3.5 \pm 1.5$ & $12.0 \pm 1.0$ & $200.3(\mathrm{r}=1.73 \pm 0.10 \mathrm{~cm} ; \mathrm{L}=22.06 \pm 1.49 \mathrm{~cm})$ & 0.06 \\
Green bean & $0.5 \pm 0.5$ & $1.5 \pm 0.5$ & $13.06(\mathrm{r}=0.53 \pm 0.03 \mathrm{~L}=13.75 \pm 1.31 \mathrm{~cm})$ & 0.115 \\
\hline
\end{tabular}

Sci. Agric. (Piracicaba, Braz.), v.61, n.6, p.655-658, Nov./Dec. 2004 


\section{ACKNOWLEDGEMENT}

To FAPESP for financial support.

\section{REFERENCES}

AMERICAN SOCIETY OF HEATING, REFRIGERATING AND AIRCONDITIONING ENGINEERING - ASHRAE Systems and Applications. Methods of precooling of fruits, vegetables and flowers. Atlanta, 1994.

BAIRD, C.D.; GAFFNEY, J.J. An numerical procedure for calculating heat transfer in bulk loads of fruits or vegetables. ASHRAE Transactions, v.82, p.525-535, 1976.

DELGADO, A.E.; WEN SUN, D. Heat and mass transfer models for predicting freezing process - a review. Journal of Food Engineering, v.47, p.157-174, 2001.

DINCER, I.; GENCELI, O.F. Cooling process and heat transfer parameters of cylindrical products cooled both in water and air. International Journal Heat Transfer, v.37, p.625-633, 1994.

DINCER, I.; YILDIZ, M.; LOKER, M.; GUN, H. Process parameters for hydrocooling apricot, plums and peaches. International Journal of Food Science and Technology, v.27, p.347-352, 1992.

FRASER, H.; OTTEN, L. Predicting $7 / 8$ cooling times for peaches by comparing heat transfer modelling and field measurement methods. St Joseph: ASAE, 1992. 10p. (Paper, 92-6016).
MITCHELL, F.G. The need for cooling. In: KADER, A.A. (Ed.) Postharvest technology of horticultural crops. 2ed. Berkley: Division of Agriculture and Natural Resources, University of California, 1992. p.53-56. (Publication, 3311).

MOHSENIN, N.N. Thermal properties of foods and agricultural materials. New York: Gordon and Beach, 1980. 405p.

TALBOT, M.T.; CHAU, K.V. Precooling strawberries. Gainesville: Institute of Food and Agricultural Sciences, University of Florida, 1991. 8p. (Circular, 942).

TERUEL M.B.J.; CORTEZ, L.A.B.; LEAL, P.M.; LIMA, G.A.B. Estudo teórico do resfriamento com ar forçado de frutas de geometrias diferentes. Revista Ciência e Tecnologia dos Alimentos, v.21, p.228-235, 2001.

TERUEL, B.; CORTEZ, L.; NEVES, L. Estudo comparativo do resfriamento de laranja Valência em três sistemas de resfriamento. Revista Brasileira de Engenharia Agrícola e Ambiental, v.5, p.481-486, 2002.

VAN DER SMAN, R.G.M. Simple model for estimating heat and mass transfer in regular-shaped foods. Journal of Food Engineering, v.60, p.383-390, 2003.

Received September 26, 2003

Accepted September 13, 2004 